\title{
Toxicogenomic-based approaches predicting liver toxicity in vitro
}

\author{
P. Godoy $\cdot$ H. M. Bolt
}

Published online: 16 June 2012

(c) Springer-Verlag 2012

Toxicogenomic-based approaches represent a powerful tool for the identification of toxic pathways in vivo (Ellinger-Ziegelbauer et al. 2008; Fielden et al. 2007) and for gene signatures that predict carcinogenic events and tumor development (Schmidt et al. 2008; 2012; Cadenas et al. 2010; Petry et al. 2010). The most successful studies in the field of Toxicology have thus far relied on in vivo exposure of laboratory animals. These studies have correctly predicted the carcinogenicity of compounds and whether they can be categorized as genotoxic or nongenotoxic carcinogens from gene expression alterations in liver tissue (Fielden et al. 2011; Ellinger-Ziegelbauer et al. 2008). However, until today, systematic classification studies have only been performed in vivo. Cultivated hepatocytes have always been a well-accepted tool to study drug metabolism enzyme induction, cytotoxicity and signal transduction (Hewitt et al. 2007; Vinken et al. 2011; Bolt and Stewart 2010; Knobeloch et al. 2012; Meyer et al. 2011; Ilowski et al. 2010; 2011; Hoehme et al. 2010; Watanabe et al. 2011; Nakagawa et al. 2011; Drobná et al. 2010). However, their use in toxicogenomics is still problematic (Godoy et al. 2010a, b; Schug et al. 2008). When hepatocytes are isolated from the liver and brought into culture, they have a propensity to dedifferentiate displaying features of epithelial to mesenchymal transition (Godoy et al. 2009, 2010a, b). This process also takes place in three-dimensional cell systems, such as the sandwich culture. This is especially apparent during the first $24 \mathrm{~h}$ in culture when a large number of genes are up- or down-

P. Godoy $(\bowtie) \cdot$ H. M. Bolt

Leibniz Institut für Arbeitsforschung an der TU Dortmund, Leibniz Research Centre for Working Environment and Human Factors (IfADo), Ardeystrasse 67, 44139 Dortmund, Germany

e-mail: godoy@ifado.de regulated as a consequence of cell isolation and culture conditions (Zellmer et al. 2010). Therefore, it should be critically evaluated whether test compound-induced gene expression alterations under conditions of an "unstable background" can be identified. Previous studies were rather discouraging. For example, Kienhuis et al. (2009) reported that there is almost no overlap between gene expression alterations induced by paracetamol in the livers of rats compared to cultivated hepatocytes. To systematically address the possible in vitro/in vivo discrepancy, Heise and colleagues (Heise et al. 2012) compared gene expression alterations induced by carcinogens in rat livers and in cultivated hepatocytes. They observed that expression alterations in genes associated with stress response, metabolism and DNA repair showed a significant in vivo/in vitro correlation (Heise et al. 2012). In contrast, genes associated with proliferation did not lead to similar results in vivo and in vitro. One explanation may be that the in vitro hepatocyte system, in contrast to the in vivo liver, could not undergo replacement proliferation after killing of hepatocytes by the test compounds. Overall, the results (Heise et al. 2012) demonstrate the importance of studying the in vitro functions that are maintained and those that no longer work in an in vivo-like manner. In the future, it will be interesting to learn whether the genes that still show in vivo-like responses in culture offer a sufficient basis for toxicogenomic approaches in vitro.

\section{References}

Bolt HM, Stewart JD (2010) Arsenic: metabolism and transport mechanisms in human hepatocytes. Arch Toxicol 84(1):1-2

Cadenas C, Franckenstein D, Schmidt M, Gehrmann M, Hermes M, Geppert B, Schormann W, Maccoux LJ, Schug M, Schumann A, 
Wilhelm C, Freis E, Ickstadt K, Rahnenführer J, Baumbach JI, Sickmann A, Hengstler JG (2010) Role of thioredoxin reductase 1 and thioredoxin interacting protein in prognosis of breast cancer. Breast Cancer Res 12(3):R44

Drobná Z, Walton FS, Paul DS, Xing W, Thomas DJ, Stýblo M (2010) Metabolism of arsenic in human liver: the role of membrane transporters. Arch Toxicol 84(1):3-16 (review)

Ellinger-Ziegelbauer H, Gmuender H, Bandenburg A, Ahr HJ (2008) Prediction of a carcinogenic potential of rat hepatocarcinogens using toxicogenomics analysis of short-term in vivo studies. Mutat Res 637(1-2):23-39

Fielden MR, Brennan R, Gollub J (2007) A gene expression biomarker provides early prediction and mechanistic assessment of hepatic tumor induction by nongenotoxic chemicals. Toxicol Sci 99(1):90-100

Fielden MR, Adai A, Dunn RT 2nd, Olaharski A, Searfoss G, Sina J, Aubrecht J, Boitier E, Nioi P, Auerbach S, Jacobson-Kram D, Raghavan N, Yang Y, Kincaid A, Sherlock J, Chen SJ, Car B, On behalf of the Predictive Safety Testing Consortium, CW (2011) Development and evaluation of a genomic signature for the prediction and mechanistic assessment of nongenotoxic hepatocarcinogens in the rat. Toxicol Sci 124(1):54-74

Godoy P, Hengstler JG, Ilkavets I, Meyer C, Bachmann A, Müller A, Tuschl G, Mueller SO, Dooley S (2009) Extracellular matrix modulates sensitivity of hepatocytes to fibroblastoid dedifferentiation and transforming growth factor beta-induced apoptosis. Hepatology 49(6):2031-2043

Godoy P, Schug M, Bauer A, Hengstler JG (2010a) A) Reversible manipulation of apoptosis sensitivity in cultured hepatocytes by matrix-mediated manipulation of signaling activities. Methods Mol Biol 640:139-155

Godoy P, Lakkapamu S, Schug M, Bauer A, Stewart JD, Bedawi E, Hammad S, Amin J, Marchan R, Schormann W, Maccoux L, von Recklinghausen I, Reif R, Hengstler JG (2010b) Dexamethasonedependent versus -independent markers of epithelial to mesenchymal transition in primary hepatocytes. Biol Chem 391(1):73-83

Heise T, Schug M, Storm D, Ellinger-Ziegelbauer H, Ahr HJ, Hellwig B, Rahnenfuhrer J, Ghallab A, Guenther G, Sisnaiske J, Reif R, Godoy P, Mielke H, Gundert-Remy U, Lampen A, Oberemm A, Hengstler JG (2012) In vitro-in vivo correlation of gene expression alterations induced by liver carcinogens. Curr Med Chem 19(11):1721-1730

Hewitt NJ, Lechón MJ, Houston JB, Hallifax D, Brown HS, Maurel P, Kenna JG, Gustavsson L, Lohmann C, Skonberg C, Guillouzo A, Tuschl G, Li AP, LeCluyse E, Groothuis GM, Hengstler JG (2007) Primary hepatocytes: current understanding of the regulation of metabolic enzymes and transporter proteins, and pharmaceutical practice for the use of hepatocytes in metabolism, enzyme induction, transporter, clearance, and hepatotoxicity studies. Drug Metab Rev 39(1):159-234 (review)

Hoehme S, Brulport M, Bauer A, Bedawy E, Schormann W, Hermes M, Puppe V, Gebhardt R, Zellmer S, Schwarz M, Bockamp E, Timmel T, Hengstler JG, Drasdo D (2010) Prediction and validation of cell alignment along microvessels as order principle to restore tissue architecture in liver regeneration. Proc Natl Acad Sci USA 107(23):10371-10376

Ilowski M, Putz C, Weiss TS, Brand S, Jauch KW, Hengstler JG, Thasler WE (2010) Augmenter of liver regeneration causes different kinetics of ERK1/2 and Akt/PKB phosphorylation than EGF and induces hepatocyte proliferation in an EGF receptor independent and liver specific manner. Biochem Biophys Res Commun 394(4):915-920
Ilowski M, Kleespies A, de Toni EN, Donabauer B, Jauch KW, Hengstler JG, Thasler WE (2011) Augmenter of liver regeneration (ALR) protects human hepatocytes against apoptosis. Biochem Biophys Res Commun 404(1):148-152

Kienhuis AS, van de Poll MC, Wortelboer H, van Herwijnen M, Gottschalk R, Dejong CH, Boorsma A, Paules RS, Kleinjans JC, Stierum RH, van Delft JH (2009) Parallelogram approach using rat-human in vitro and rat in vivo toxicogenomics predicts acetaminophen-induced hepatotoxicity in humans. Toxicol Sci 107(2):544-552

Knobeloch D, Ehnert S, Schyschka L, Büchler P, Schoenberg M, Kleeff J, Thasler WE, Nussler NC, Godoy P, Hengstler J, Nussler AK (2012) Human hepatocytes: isolation, culture, and quality procedures. Methods Mol Biol 806:99-120

Meyer C, Godoy P, Bachmann A, Liu Y, Barzan D, Ilkavets I, Maier P, Herskind C, Hengstler JG, Dooley S (2011) Distinct role of endocytosis for Smad and non-Smad TGF- $\beta$ signaling regulation in hepatocytes. J Hepatol 55(2):369-378

Nakagawa Y, Suzuki T, Ishii H, Nakae D, Ogata A (2011) Cytotoxic effects of hydroxylated fullerenes on isolated rat hepatocytes via mitochondrial dysfunction. Arch Toxicol 85(11):1429-1440

Petry IB, Fieber E, Schmidt M, Gehrmann M, Gebhard S, Hermes M, Schormann W, Selinski S, Freis E, Schwender H, Brulport M, Ickstadt K, Rahnenführer J, Maccoux L, West J, Kölbl H, Schuler M, Hengstler JG (2010) ERBB2 induces an antiapoptotic expression pattern of $\mathrm{Bcl}-2$ family members in node-negative breast cancer. Clin Cancer Res 16(2):451-460

Schmidt M, Böhm D, von Törne C, Steiner E, Puhl A, Pilch H, Lehr HA, Hengstler JG, Kölbl H, Gehrmann M (2008) The humoral immune system has a key prognostic impact in node-negative breast cancer. Cancer Res 68(13):5405-5413

Schmidt M, Hellwig B, Hammad S, Othman A, Lohr M, Chen Z, Boehm D, Gebhard S, Petry I, Lebrecht A, Cadenas C, Marchan R, Stewart JD, Solbach C, Holmberg L, Edlund K, Kultima HG, Rody A, Berglund A, Lambe M, Isaksson A, Botling J, Karn T, Müller V, Gerhold-Ay A, Cotarelo C, Sebastian M, Kronenwett R, Bojar H, Lehr HA, Sahin U, Koelbl H, Gehrmann M, Micke P, Rahnenführer J, Hengstler JG (2012) A comprehensive analysis of human gene expression profiles identifies stromal immunoglobulin $\kappa \mathrm{C}$ as a compatible prognostic marker in human solid tumors. Clin Cancer Res 18(9):2695-2703

Schug M, Heise T, Bauer A, Storm D, Blaszkewicz M, Bedawy E, Brulport M, Geppert B, Hermes M, Föllmann W, Rapp K, Maccoux L, Schormann W, Appel KE, Oberemm Oberemm A, Gundert-Remy U, Hengstler JG (2008) Primary rat hepatocytes as in vitro system for gene expression studies: comparison of sandwich, Matrigel and 2D cultures. Arch Toxicol 82(12): 923-931

Vinken M, Decrock E, Doktorova T, Ramboer E, De Vuyst E, Vanhaecke T, Leybaert L, Rogiers V (2011) Characterization of spontaneous cell death in monolayer cultures of primary hepatocytes. Arch Toxicol 85(12):1589-1596

Watanabe T, Ohta Y, Mizumura A, Kobayashi Y, Hirano S (2011) Analysis of arsenic metabolites in HepG2 and AS3MT-transfected cells. Arch Toxicol 85(6):577-588

Zellmer S, Schmidt-Heck W, Godoy P, Weng H, Meyer C, Lehmann T, Sparna T, Schormann W, Hammad S, Kreutz C, Timmer J, von Weizsäcker F, Thürmann PA, Merfort I, Guthke R, Dooley S, Hengstler JG, Gebhardt R (2010) Transcription factors ETF, $\mathrm{E} 2 \mathrm{~F}$, and SP-1 are involved in cytokine-independent proliferation of murine hepatocytes. Hepatology 52(6):2127-2136 